\title{
The Post-War Reconstruction Project
}

\author{
Stuart Macintyre
}

Yet out of evil cometh good.

- John Dedman, tabling the White Paper

on Full Employment ${ }^{1}$

Post-War Reconstruction is a term with a distinct Australian resonance. All of the participants in the Second World War had aims that informed their planning of arrangements for the end of hostilities. Among the Allies these goals found expression in the Atlantic Charter of August 1941, whereby Churchill and Roosevelt affirmed the principles on which their countries based 'their hopes for a better future for the world'. The principles included the assurance that 'all the men in all the lands may live out their lives in freedom from fear and want'. The two freedoms were drawn from President Roosevelt's State of the Union address at the beginning of 1941, and he took the other two freedoms it enunciated, freedom of speech and freedom of worship, as implicit in the Charter. $^{2}$

For the first year of his premiership, Churchill had resisted any statement of Britain's objectives; he said later that the planners of the post-war order should not overlook the recipe given in a cookery book for jugged hare, which began 'First catch your hare'. ${ }^{3}$ But Roosevelt's State of the Union address was intended to reconcile the American public to the Lend-Lease scheme and therefore included a provision for free trade, which inevitably drew the Allies into protracted negotiations over the post-war economic order.

In any case, there were insistent pressures in wartime Britain for a post-war commitment, especially after the Labour Party entered the government and the Beveridge Report identified freedom from want as one of 'the five giants on the road of reconstruction', the others being 'disease, ignorance, squalor and

\footnotetext{
1 Digest of Decisions and Announcements, 103 (26 May - 14 June 1945), 11.

2 W.L. Langer and S.E. Gleason, The World Crisis and American Foreign Policy: The Undeclared War (London: Royal Institute of International Affairs, 1953), chs 9, 21.

3 D. Reynolds, "The Atlantic "Flop": British Foreign Policy and the Churchill-Roosevelt Meeting of August $1941^{\prime}$, in D. Brinkley and D.R. Facey-Crowther, eds, The Atlantic Charter (New York: St Martin's Press, 1994), 129-50.
} 
idleness' ${ }^{4}$ Duff Cooper, the minister of information, persuaded the War Cabinet in August 1940 to establish a sub-committee on war aims, and Labour's Arthur Greenwood assumed ministerial responsibility for the Reconstruction Committee in January 1941; his colleague, William Jowitt, was appointed minister in charge of reconstruction in February 1942. Other ministers began planning post-war projects and numerous non-government organisations contributed their own blueprints. It was the same in Canada, where the president of McGill University chaired an Advisory Committee on Reconstruction from 1941 to 1943, and then C.D. Howe, a senior member of Mackenzie King's Cabinet, was appointed minister of reconstruction. ${ }^{5}$ New Zealand followed a similar course of consultation and planning.

There was a marked similarity also in the range of activities that the Allies envisaged. An immediate task would be demobilisation, repatriation and rehabilitation of members of the armed forces, along with generous schemes of education and training. Then there was the conversion of the wartime economy to civilian production, including disposal of assets and redeployment of munitions workers. All the Allies embraced full employment as an official objective and issued statements that explained how government would manage the economy to sustain growth. Making good the backlog of housing was another priority, along with restoration of investment in industry and public utilities. While New Zealand and the United States had introduced measures of social welfare during the 1930s, they joined the other Allies in extending income support and increasing provision for health and education. Population policy was a common concern, joined to ambitious schemes of immigration. Town planning and community development were also prominent.

All these initiatives made for an expansion of government and an enlargement of citizenship, but it was only in Australia that they were comprehended under the rubric of post-war reconstruction. That term had restricted currency in the United States, which emerged from the war as the dominant world power. Its Gross Domestic Product doubled between 1939 and 1945, providing both guns and butter, and a Gallup poll early in 1945 found that only 36 per cent of respondents believed they had made any real sacrifice for the war. ${ }^{6}$ While the United States took on new international responsibilities after the war, it did not see any need to plan new domestic arrangements; on the contrary, the task was to return the country to normality as quickly as possible. Canada enjoyed a good war for it too served as an arsenal for the Allied forces. ${ }^{7}$ When Douglas

\footnotetext{
4 P. Addison, The Road to 1945: British Politics and the Second World War (London: Jonathon Cape, 1975; rev. edn, London: Pimlico, 1994), 17.

5 R. Bothwell and W. Kilbourn, C.D. Howe: A Biography (Toronto: McClelland and Stewart, 1979), ch. 12.

6 J. Gilbert, Another Chance: Postwar America, 1945-1968 (Philadelphia: Temple University Press, 1981), 8.

7 The World Economy: Volume 1: A Millennial Perspective; Volume 2: Historical Statistics (Paris: OECD, 2006), 462.
} 
Copland, the Australian Prices Commissioner, visited Canada early in 1945, he was struck by the country's prosperity - industry was booming, most goods were in ample supply and, when he asked what was happening in the Ministry of Reconstruction, he found that it was principally concerned with the disposal of government-owned plant and equipment. ${ }^{8}$

The United Kingdom, on the other hand, emerged from the war exhausted and impoverished. Reconstruction was undoubtedly necessary to make good the effects of the blitz, yet the Attlee Government embarked on an economic and social program of heroic proportions while struggling to preserve the country's status as a world power. The Labour Party's electoral program in 1945 was entitled, Let Us Face the Future, but those who set about doing so coined far grander phrases: they were creating 'The New Order', building a 'New Jerusalem' that would support all citizens 'From Cradle to Grave'. ${ }^{9}$ Talk of reconstruction, so common in early wartime discussion, fell into disuse, partly because it reminded many Britons of the conspicuous failure of an earlier ministry of that name created during the First World War to redeem David Lloyd George's pledge of 'A Land Fit for Heroes'. For that matter, the associations in the United States were equally unattractive. The Reconstruction that followed the Civil War (which seems to be where the term originated) had only compounded the rancour of the former Confederate states.

Rehabilitation and reconstruction were included in the functions of the Department of Labour and National Service created in October 1940; a Reconstruction Division was established in that department at the end of the year, and in February 1941 an interdepartmental committee was formed to coordinate the planning. The new Labor Government attached the term to a variety of initiatives taken during the critical phase of the war against Japan. In opening the Constitutional Convention in November 1942, John Curtin explained that extensive new powers were required for 'the vital task of postwar reconstruction'. Following the undertaking by the states that they would transfer these powers to the Commonwealth, he formed the Department of PostWar Reconstruction. ${ }^{10}$

By this time reconstruction had taken on an enlarged meaning. When Roland Wilson, who as head of the Department of Labour and National Service guided the initial work of the Reconstruction Division, appeared before the Parliamentary Committee on Social Services to explain progress, he conceded that the word could mean constructing again or constructing anew, but suggested that reconstruction should be distinguished from restoration. Its usage, he noted,

8 'Notes on 1944-45 Trip', 9 February 1945, Copland Papers, National Library of Australia (NLA) MS 3800, Box 152.

9 P. Clarke, The Last Thousand Days of the British Empire (London: Allen Lane, 2007), 309.

10 Digest of Decisions and Announcements, 46 (12 November - 6 December 1942), 22. 
stretched from the 'severely practical and rather humdrum tasks' of beating swords into ploughshares to the 'aspirations of a people to build Jerusalem in Australia's brown and pleasant land'. ${ }^{11}$

It was the work of the Department of Post-War Reconstruction that gave the term its expanded Australian valency. New Zealand provides an instructive contrast for there was a marked similarity between the two countries in the scale of their war effort and the methods they employed to sustain it, as well as a close correspondence of their post-war aspirations. But New Zealand chose to pursue them through a Cabinet sub-committee of senior ministers and an executive committee of the departmental heads, coordinating activity by means of an Organisation for National Development located within the Prime Minister's Department and generating a host of national and regional planning committees. This unwieldy structure was impractical and soon abandoned. ${ }^{12}$ Canada briefly used a Department of Reconstruction, but C.D. Howe preferred to work through his major portfolio of Munitions and Supply, and was unsympathetic to the expansive schemes devised by the earlier Committee on Reconstruction. ${ }^{13}$ Similarly, the British Ministry remained small and devoid of substantial responsibilities. Accordingly the appellation fell into disuse. Few Australians remarked on its persistence here, and Australian historians took it over as a shorthand term for an epoch and an ethos.

The Department of Post-War Reconstruction contained three of the seven dwarfs - Dr H.C. Coombs, J.G. Crawford and Allen Brown. It emerged out of another department headed by a fourth dwarf, Dr Roland Wilson, and nurtured a remarkable number of future departmental heads - Harold Breen, John Bunting, Lenox Hewitt, John Knott, Cecil (Eske) Lambert, Peter Lawler, Charles McFadyen, William McLaren, Arthur Tange and Geoffrey Yeend. All three heads of the Prime Minister's Department between 1949 and 1971 were former officers of Post-War Reconstruction. Established at a time when Prime Minister's was little more than a secretariat and Treasury a budget office, the new department was able to initiate policy. It had powerful ministers in Chifley and Dedman. A new creation, it recruited extensively from outside the ranks of the pre-war public service and thus escaped the overhang of ageing ex-AIF functionaries. The leading officers were young university graduates who flourished as the Commonwealth Public Service (CPS) took on a new professionalism.

\footnotetext{
11 'Research on Internal Subjects, Economic and Social - Evidence Submitted to the Social Security Committee', 20 June 1942, National Archives of Australia (NAA) A9816, 1943/413.

12 J.V.T. Baker, The New Zealand People at War: War Economy (Wellington: Historical Publications Branch, Department of Internal Affairs, 1965), 527-30.

13 R. Bothwell, I. Drummond and J. English, Canada since 1945: Power, Politics and Provincialism (Toronto: University of Toronto Press, 1981), 65-9.
} 


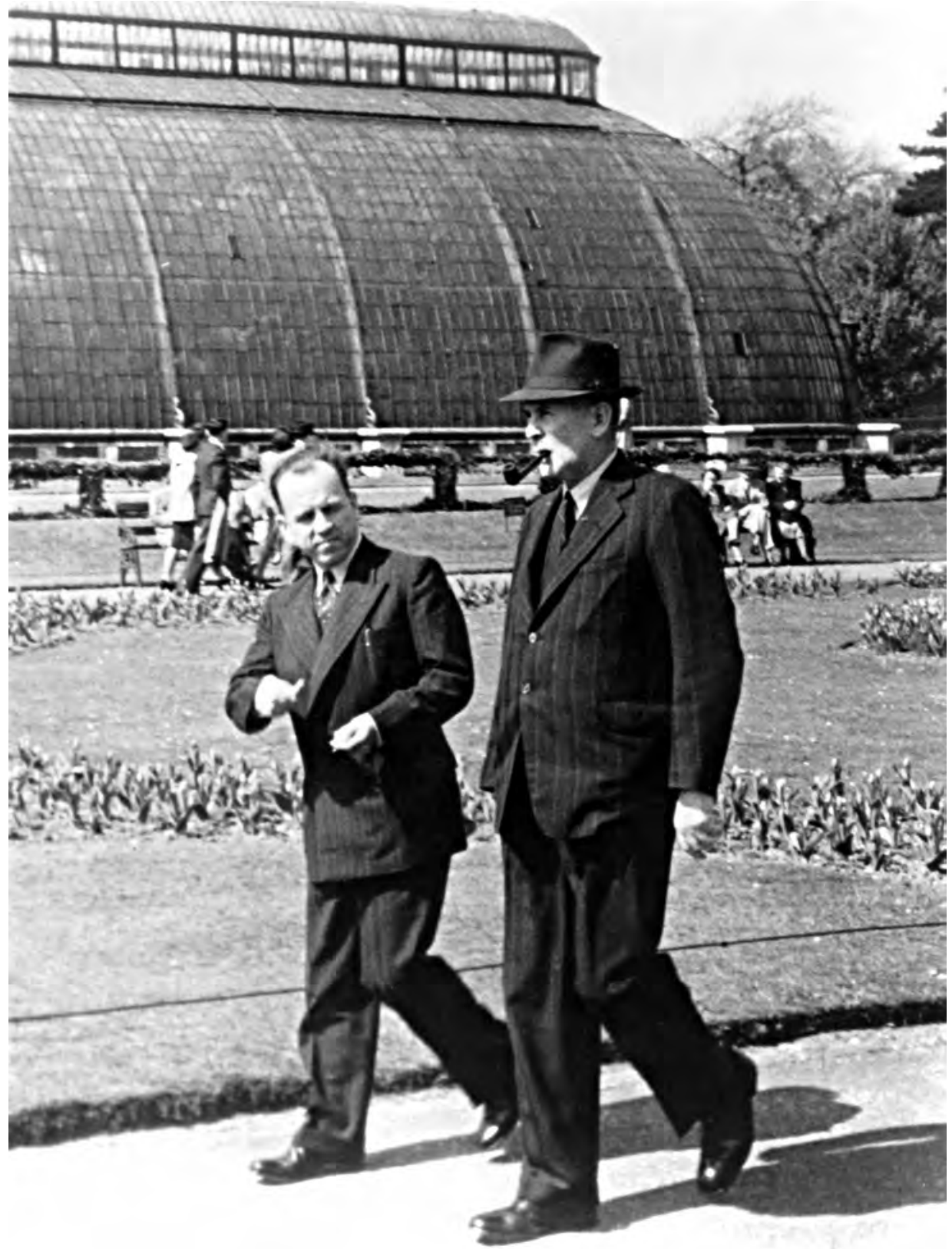

H.C. Coombs with Prime Minister Ben Chifley in London, 1946

Source: National Archives of Australia, M2153, 6/2 
Yet the department was also a product of wartime improvisation, a somewhat belated device to bring together a number of disparate ventures. Initially, it was not intended to undertake administrative activities; rather, it would support and coordinate the work of commissions of inquiry on rural reconstruction, housing, public works and secondary industry (and for this reason it was initially designated as a ministry), and then plan their implementation by other departments (so that it was represented in a very wide range of interdepartmental committees). It soon embarked on additional activities - such as immigration, regional planning and community development - that were usually suggested by Coombs as director-general to Chifley as minister and justified by their relevance to the declared goals of national development, full employment and rising living standards. Some of the proposed commissions, such as one on public works, fell victim to obstruction by the states; others, such as education and Aboriginals, were rejected by Chifley, who enjoyed close relations with Coombs but remained instinctively cautious. The department also acquired administrative functions, some of them taken over from the Department of War Organisation of Industry when that department was absorbed in 1945, and then hived off to other departments before its abolition at the end of the decade. In 1945 it had a staff complement of just under $1,000 .{ }^{14}$

The results were uneven. Coombs' energetic leadership was interrupted by long periods abroad and some of the divisional heads lacked his political acumen. The failure of the Commonwealth to obtain the additional powers sought by referendum in 1944 necessitated reliance on the cooperation of the often uncooperative states; among the casualties were the housing program and the scheme for technical training. The abrupt conclusion of the Pacific War threw plans for an orderly transition into disarray. So, too, the immediate cessation of the Lend-Lease program, the dollar shortage and deteriorating industrial relations imposed severe constraints on the plans for industrial development. With the onset of the Cold War, a deteriorating political climate diminished the public support on which post-war reconstruction was premised.

Most of all, the project was seriously handicapped by its association with wartime austerity. A country that was weary of manpower direction, regulation and rationing, expected peace to bring relief from state control. It did not help that Coombs had been director of Rationing and Dedman was remembered as the man who cancelled Christmas.

14 First Report of the Committee of Review of Civil Staffing of Wartime Activities, 27 July 1945, NAA M448, 105. 


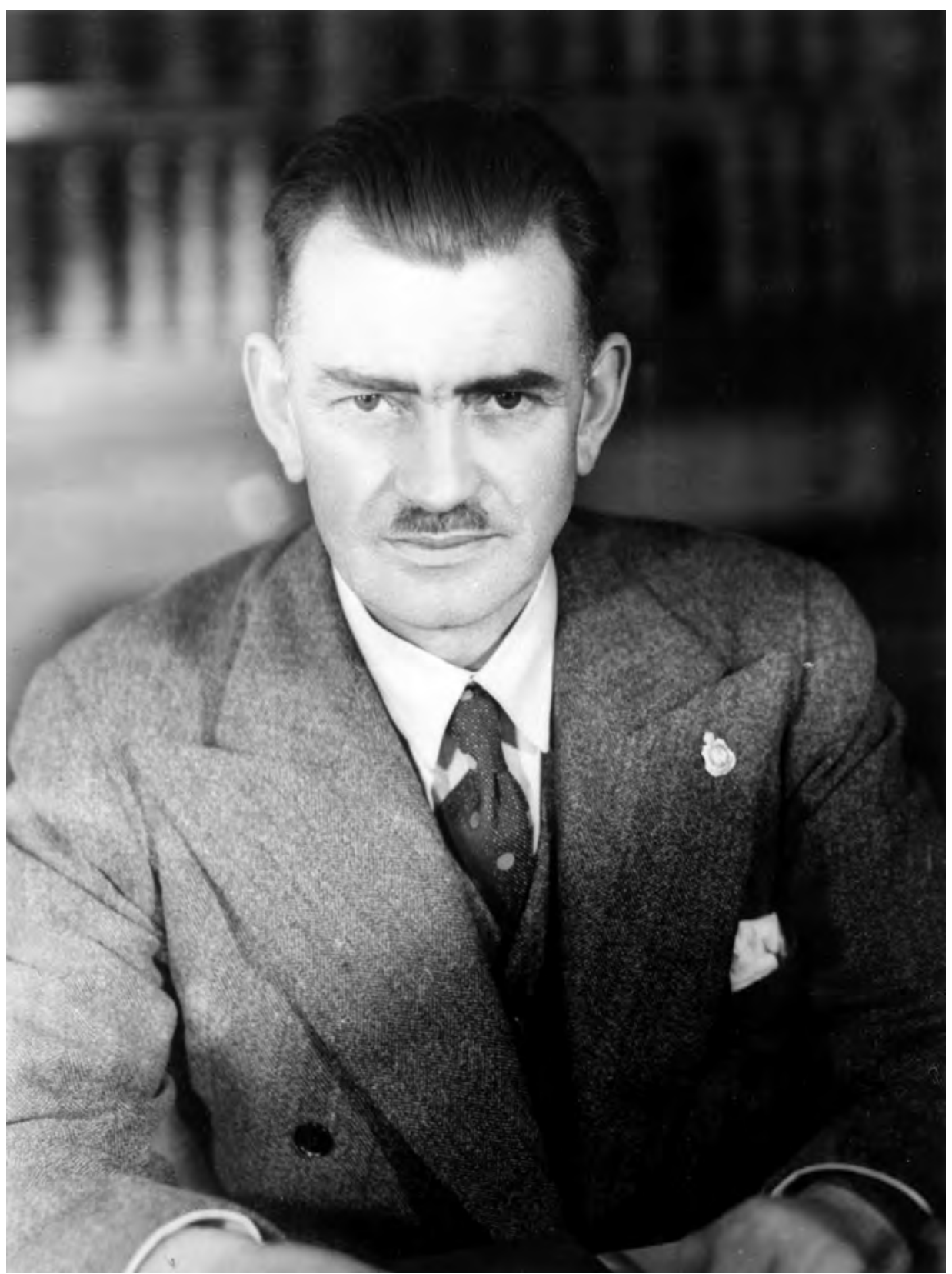

John Dedman, 1941

Source: Australian War Memorial, 010015 
Closely linked to this mood of disenchantment was a suspicion of the planner. Joanne Pemberton has noted how the idea of planning was born out of the misery and chaos of the inter-war years. The wartime emergency brought intellectuals confident of their capacity to build a new order on the ruins of the old into new positions of influence, and planning achieved a 'rhetorical dominance'. ${ }^{15}$ But their participation in a Labor government steeped in ancestral memories of class conflict meant that planning lost its earlier connotations of science and social progress. As demonstrated in the all-too-frequent paeans to planning delivered by Lloyd Ross, the director of Public Relations in the Department of Post-War Reconstruction, it had become a political creed. ${ }^{16}$

Paul Hasluck writes in the second volume of his war history that '[i]n the public service, and on the fringes of the public service, in various agencies created for the purpose, there grew up towards the end of the war a group of persons who might best be described as the planners'. But Hasluck was himself an early planner, the joint secretary of the Inter-Departmental Committee on External Relations established in 1941, and head of the post-war section of the Department of External Affairs created in April 1942. He goes on to suggest that:

The planners were a new phenomenon in Australian government and the administrative arrangements made for post-war reconstruction gave them unusual opportunities. They were a new and devout group who had believed in the planned state and had communed about it when they were only a devout few in the political catacombs, and now the Emperor himself had embraced their religion. ${ }^{17}$

Ronald Walker takes a different perspective. An early adviser to government on post-war reconstruction, and then deputy director-general of the Department of War Organisation of Industry, he was better placed to assess the transformation of the public service. In his subsequent account of The Australian Economy in War and Reconstruction, he noted how the sudden expansion of wartime administration spawned many new departments and directorates, with overlapping functions, inconsistent reporting lines and a maze of interdepartmental committees and councils to coordinate their efforts. Generally speaking, he observed, federal ministers took a less active part in the administration of their departments than their state counterparts and permanent heads carried a heavier burden of

15 J. Pemberton, 'The Middle Way: The Discourse of Planning in Britain, Australia and the League in the Interwar Years', Australian Journal of Politics and History, 52, no. 1 (2006), 48-63; “'O Brave New Social Order": The Controversy Over Planning in Australia and Britain in the 1940s', Journal of Australian Studies, 83 (2004), 35-47.

16 L. Ross, 'A New Social Order', in D.A.S. Campbell, ed., Post-War Reconstruction in Australia (Sydney: Australian Publishing Company in conjunction with the Australian Institute of Political Science, 1944), 183-237.

17 P. Hasluck, The Government and the People 1942-1945 (Canberra: Australian War Memorial, 1970), 445. 
responsibility. The absence of a senior administrative class, as in Britain or the United States, made it necessary to recruit from business, the universities and the legal profession. ${ }^{18}$

In Walker's opinion, businessmen often found it difficult to adapt to different methods and expectations, though they quickly acquired 'the civil-service custom of appraising the status of an officer by the number of drawers in his desk'. The lawyers, with their familiarity with paperwork and orderly minds, were more easily absorbed. Academics brought a certain literary facility and an ability to master large bodies of information, and Walker judged them to be readier than businessmen to appreciate the professional qualities of the regular public servant. He singled out his own profession: 'the building of the war-time administrative machine fell very largely to economists' ${ }^{19}$

Walker might be thought here to be indulging in self-service, though he acknowledged that the economists who acquired executive duties were not always viewed favourably by members of the permanent public service or the public, which expected them to advise on policy rather than execute it. 'If the Australian public service were nearer the British in quality', he added, 'economists would not have figured so prominently in war administration' and could have made a greater contribution as expert advisers. ${ }^{20}$ L.F. Giblin, the father figure of the economics profession, who exercised considerable influence from the chair of the advisory Financial and Economic Committee, judged that Australian economists possessed 'an acute political sense'. They were frequently 'more practical and realistic than the business men' and thus given responsibility for some of the 'most acutely practical' administrative tasks such as price control, rationing and labour allocation. "The word of complaint or abuse is "academic"; but in truth they are the least academic of God's creatures.' ${ }^{21}$

There were indeed complaints of impractical academics invading the public service. The director of the Associated Chamber of Manufacturers denounced the 'economists, ranging in hue from full pink to deep red mostly deep red' who had descended upon Canberra to impose their schemes on the nation. ${ }^{22}$ Arthur Fadden, the leader of the Opposition, criticised the Curtin Government's reliance upon 'men who had little or no experience of business and industrial life' ${ }^{23}$ His Country Party colleague, Larry Anthony, decried the 'itch to interfere on the part of professors, economists and other cap-and-gown gentlemen' ${ }^{24}$

\footnotetext{
18 E.R. Walker, The Australian Economy in War and Reconstruction (New York: Oxford University Press, 1947), ch. 5.

19 Ibid., 126-8.

20 Ibid., 128.

21 L.F. Giblin, 'Reconstruction in Australia', Agenda: A Quarterly Journal of Reconstruction, 2, no. 3 (1943), 216.

22 'Pink and Red Economists Find Sanctuary in ACT', Canberra Times, 14 April 1943.

23 'Mr Fadden Attacks New Department', Sydney Morning Herald, 18 August 1943.

24 Commonwealth Parliamentary Debates, 173 (3 February 1943), 245.
} 
We should remember also the advice given by Copland when the head of the Prime Minister's Department asked why his assistant was occupying a bench in the parliamentary gardens: 'Mr Downing does his best work in a rose garden'. There was also the occasion when Dick Downing, resplendent in the purple scarf of his Cambridge college, entered a room in Parliament House in search of Copland. Seeing that he was interrupting a meeting chaired by the prime minister, Downing withdrew. 'Tell me', asked John Curtin, 'who was that very distinguished-looking gentleman with a bath-towel round his neck?' Informed that it was the assistant economic consultant to the prime minister, his only comment was 'Oh, indeed'. ${ }^{25}$

These observations have particular relevance for the dwarfs and other senior public servants whose careers progressed through the Department of Post-War Reconstruction. Many of them were economists seconded to government duty in an advisory role, sometimes from universities and sometimes - like Coombs, Crawford and Tange - from banks. They soon became administrators and were caught up in the tangled web of wartime decision-making. Some returned subsequently to academic posts, while others stayed on to put their stamp on public policy over the following decades. And perforce their duties in the Department of Post-War Reconstruction meant that they were all planners.

In the space that is available to me I shall trace out these patterns in the formative wartime years. I suggest there were two phases. The first lasted from late 1940 to the end of 1942, when the planning of post-war reconstruction was neglected and ineffective. The second begins with the advent of Coombs as directorgeneral of the new department, when planning became an urgent necessity.

The Menzies Government made provision for planning reconstruction as a result of its political difficulties. Following the election in September 1940, the Coalition lacked a majority in the House of Representatives. After protracted negotiations with Labor failed to secure a wartime National government, Menzies acceded to the conditions that Curtin attached to his support of the war effort - that there should be an Advisory War Council and that a start should be made on reconstruction planning. Hence a Reconstruction Division was included in the newly formed Department of Labour and National Service. At the beginning of 1941, Menzies formally requested Harold Holt, the minister, to investigate the tasks of postwar reconstruction and especially the re-employment of servicemen and war workers. Holt explained that the investigation would need to be coordinated with other federal departments and the Cabinet approved establishment of an InterDepartmental Advisory Committee on Reconstruction. ${ }^{26}$

25 N. Brown, “"Mr Downing Does His Best Work in a Rose Garden”: An Economist in Canberra in the 1940s', Canberra Bulletin of Public Administration, 80 (September 1996): 33-45; G. Firth to H. Arndt, 4 June 1976, Firth Papers, NLA Acc. 01/273, Box 9A.

26 Minister for Labour and National Service, 'Co-ordination of Reconstruction Planning', 7 February 1941, 


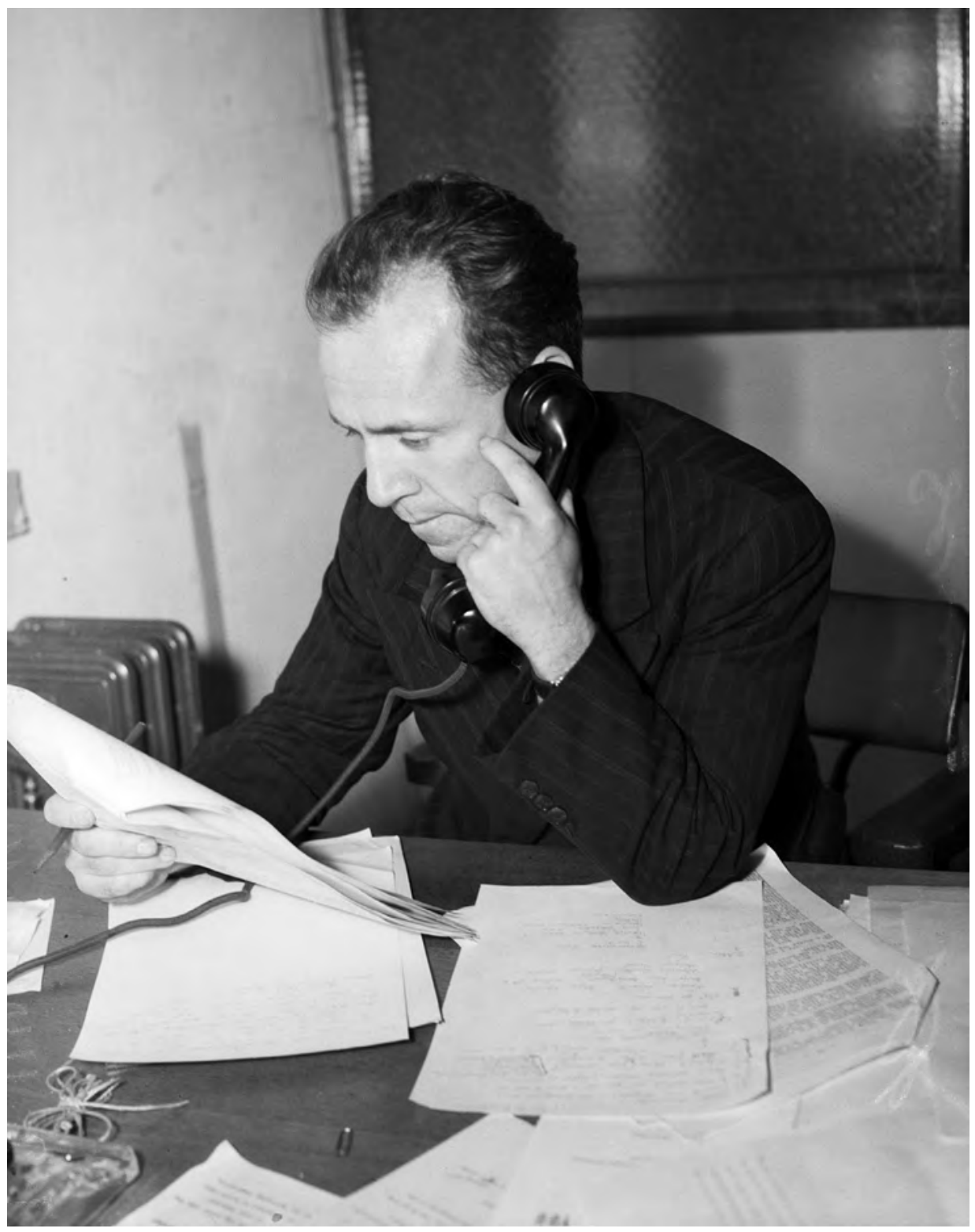

\section{Dr H.C. (Nugget) Coombs, 1942}

Source: Australian War Memorial, 136412 
Ronald Wilson accordingly invited representatives of the service departments, Postmaster-General's, Supply and Development, Trade and Customs, the Treasury, the Tariff Board, the Prices Commissioner, the Coordinator-General of Works, the Repatriation Commission, the Financial and Economic Committee and the Council for Scientific and Industrial Research (CSIR) to a first meeting. The committee that assembled in Canberra on 14 March 1941 is more aptly described as a conference. It was chaired by Holt, with Herbert Evatt - the former justice of the High Court who had recently arrived in the House of Representatives and was impatient for office - accepting appointment as director of research and serving as the deputy chair. After noting some dimensions of the task, the participants decided that specialist sub-committees should pursue them. ${ }^{27}$

This was the first and last meeting of the Advisory Committee. In its aftermath a number of departmental heads submitted statements amplifying the views they had expressed at the meeting and suggesting how the sub-committees might proceed. Several were anxious to volunteer their services (so the Tariff Board took charge of investigating the post-war prospects for industry) and others warned the Advisory Committee from trespassing (hence the secretary of the Department of the Interior insisted that the committee should not concern itself with migration, and Wilson had to remind him that his department had joined its deliberations at the express request of his minister). ${ }^{28}$ Giblin, as the chair of the Financial and Economic Committee, and Copland, as Prices Commissioner, provided perceptive comments about economic aspects of reconstruction, while David Rivett, as head of the CSIR, offered the mordant observation that 'the only completely satisfactory manner of dealing with unemployment' seemed to be war. He also remarked on the paradox of reconstruction in its Australian usage: 'Reconstruction implies prior destruction. So far there has not been much destruction here ... We can therefore to an extent determine our immediate "destruction" for war purposes, with an eye to reconstruction.'29

Six sub-committees were constituted, and the one that made most substantial progress was the Inter-Departmental Committee on External Relations, which worked with Treasury, External Affairs and the Financial and Economic Committee on the implications of Article VII of the Lend-Lease scheme, which pledged Australia and other beneficiaries of American assistance to liberalise trade restrictions. The states agreed to begin their own post-war planning, but a midyear meeting of their liaison officers in Canberra revealed a low level of activity.

27 'Report of the First Meeting of the Inter-Departmental Committee on Reconstruction', NAA A9816/3, $1943 / 553$.

28 Statement by Tariff Board, 22 April 1941, NAA A9816/3, 1943/555; J.A. Carrodus, Secretary of the Department of the Interior, to R. Wilson, 2 October 1941, and Wilson to Carrodus, 24 November 1941, NAA A9816/3, 1943/441.

29 D. Rivett, 'Notes', NAA A9816/3, 1943/555. 
The universities were enlisted to undertake investigation of aspects of reconstruction, using a Commonwealth grant for social science research that Roland Wilson established, but this too was of limited utility.

These activities were coordinated by the Reconstruction Division of the department, which was also responsible for gathering and disseminating information. The Division consisted of a small group of research officers recently recruited to the public service: P.W.E. ('Pike') Curtin, a contemporary of Coombs who had studied at the London School of Economics; P.R.H. ('Perce') Judd, formerly economics teacher at Adelaide High; L.F. ('Fin') Crisp, who studied economics at Oxford as a Rhodes scholar until the outbreak of war; G.G. (Gerald) Firth, an Englishman who had come to Australia as a research fellow in the economics department of the University of Melbourne; and A.H. (Arthur) Tange, an economics graduate of the University of Western Australia who had worked for the Bank of New South Wales. Curtin and Judd were in their early thirties, the others still in their twenties. Their location in the Old Hospital Building in Canberra separated them from the rest of the department in Melbourne, though they were encouraged and assisted by E.R. Richard ('Dick') Hayward, formerly personal assistant to Wilson and now assistant-director of the Industrial Welfare Division, and K.C.O. ('Mick') Shann, Wilson's current assistant. They dealt principally with young and rising officers of the public service in Canberra, notably Fred Wheeler in the Treasury and John Burton, who had moved from Labour and National Service to External Affairs in the previous year. The Division's other function, encouraging the study of reconstruction throughout the community, was hampered by the reluctance of the Cabinet to authorise publication of the literature it prepared. ${ }^{30}$

The change of government in October 1941 brought no greater urgency. Eddie Ward, the new minister, showed a conspicuous lack of interest in this part of his portfolio and had to be prodded by Chifley to revive the Inter-Departmental Committee on External Relations so that Australia could establish its position on Article VII for imminent negotiations. ${ }^{31}$ Ward also allowed the Tariff Board to retain responsibility for advising on the post-war conversion of wartime industries, a task for which it was ill equipped. ${ }^{32}$ Chifley showed increasing interest in reconstruction during 1942, as did the Joint Parliamentary Committee on Social Security. Its fifth report, presented in October 1942, stressed the need for a comprehensive plan, criticised the Inter-Departmental Committee as too

30 Weekly reports of Division's activities, August-November 1941, NAA A9861/3, 1943/743.

31 Chifley to Ward, 18 March 1942, NAA A9816/3, 1943/441.

32 Ward, Cabinet submission, 5 May 1942, NAA M4481, 109. 
unwieldy to direct and coordinate such planning, and recommended a minister be given responsibility with the assistance of a new National Planning and Coordination Committee. ${ }^{33}$

Throughout 1942 the officers of the Reconstruction Division chafed at the restrictions they encountered. Arthur Tange, who joined it in February 1942, later recalled that 'I more than once wondered just what was expected of us and what purpose I was serving'. There was almost no direction from above the Cabinet was preoccupied with the war crisis, Wilson was more than fully occupied, and if anyone had stopped a minister or senior officer in a corridor and said he wanted to talk about post-war housing, rural reconstruction or other such matter, 'he was probably in peril of his life' ${ }^{34}$

Gerald Firth, who shared the feeling of futility, sought solace from Giblin and Copland, his former colleagues at the University of Melbourne. With Giblin's encouragement, he hit upon the idea of 'handing the whole show' over to Coombs, who was at that time adviser to the Treasury. Firth could see one impediment to such an arrangement, the unlikelihood that the head of Treasury, Stuart McFarlane, would accept responsibility for reconstruction. He did not see another, the fact that Coombs was about to become director of Rationing. Nevertheless, early in April 1942, he approached Coombs, who suggested that it might be possible to resolve the problem 'by getting Chifley to take on Reconstruction more or less as a separate portfolio - Coombs being responsible in regard to reconstruction' ${ }^{35}$ Firth assumed that Coombs' appointment a week later nullified the scheme but, from this point, Chifley assumed greater responsibility for reconstruction. In May, he took a submission prepared by the Reconstruction Division for the creation of a Rural Reconstruction Commission to Cabinet, and in August he was appointed to the chair of a new Cabinet subcommittee to coordinate and direct reconstruction planning. ${ }^{36}$

The only remaining obstacle to creation of a department was the prime minister. Throughout 1942 John Curtin was preoccupied by the threat of invasion and wanted no distraction from the urgent tasks of national mobilisation. As late as September 1942, he insisted that the government had no intention of establishing a ministry of reconstruction. ${ }^{37}$ If backbenchers such as Arthur Calwell were prepared to challenge Curtin - and Calwell claimed credit for the

33 T.H. Kewley, Social Security in Australia 1900-1972 (2nd edn, Sydney: Sydney University Press, 1973), $176-9$.

34 Arthur Tange, interviewed by J.D.B Miller, 1-23 April 1981, NLA TRC 1023; and see his memo to Coombs, 8 February 1942, Crisp Papers, NLA MS 5243/12/2.

35 Firth diary, 9-10 April 1942, NLA, Acc. 01/273.

36 Cabinet submission on 'Rural Reconstruction', NAA M448/1, 109; Digest of Decisions and Announcements, 36 (26 July - 10 August 1942), 14.

37 Digest of Decisions and Announcements, 43 (17-28 September 1942), 19. 
resolution calling for a department of post-war reconstruction carried at the federal conference of the Labor Party in November 1942 - Chifley would not gainsay the leader he served so faithfully. ${ }^{38}$

It would seem that Roland Wilson played a decisive role. This most diminutive of the seven dwarfs, aptly described by Gerald Firth as a 'redoubtable little bastard', could see that his minister was wholly unsympathetic to the work of the Reconstruction Division. ${ }^{39}$ Eddie Ward, the minister for Labour and National Service, was preoccupied with industrial relations, frequently clashing with Cabinet colleagues as he sought to strengthen the position of trade unions. Ward had little time for economists, whom he blamed for their part in designing the Premiers' Plan during the Depression, and he was suspicious of grandiose talk of a new social order. 'There is only one new order acceptable to the workers', he said in the House of Representatives during discussion of the Atlantic Charter, and 'that is the social ownership and control of production, distribution and exchange'. ${ }^{40}$ Despairing of the inaction, Wilson met with Curtin sometime in the spring of 1942 and advised him that reconstruction should be taken out of Labour and National Service and put into a new department with Coombs as its director. Curtin accepted the proposal and advised Wilson to see Chifley and talk him into accepting responsibility for it. ${ }^{41}$ It is clear that Chifley was predisposed to agree and, on 22 December 1942, he was appointed minister for Post-War Reconstruction. ${ }^{42}$

Two months earlier, Chifley had asked Coombs for advice about how the new entity might operate. The two men had already devised the Rural Reconstruction Commission as a mechanism for consultation, investigation and planning; a commission could be established under the national security regulations, gather evidence in a manner that allowed interested parties to put their case, yet operate with a level of autonomy that would protect it from capture by vested interests. Coombs envisaged additional commissions on secondary industries, housing, public works, education and Aboriginal policy. In providing these commissions with technical and research support, officers of the department would guide and direct them; collectively they would comprise a 'central reconstruction secretariat' that would ensure coherence. The problem exercising Coombs was implementation. It would be necessary to ensure the cooperation of other departments responsible for activities involved in reconstruction, and he

\footnotetext{
38 A. Calwell in Commonwealth Parliamentary Debates, 170 (6 May 1942), 913-14; and letter to Coombs, 19 January 1942, NAA M448/1, 39.

39 Firth diary, 11 November 1940.

40 Commonwealth Parliamentary Debates, 168 (21 August 1941), 99.

41 This account was given by Wilson in discussion at the 1981 Conference on Post-War Reconstruction; NLA TRC 1096.

42 Digest of Decisions and Announcements, 46 (12 November - 6 December 1942), 21-9; 48 (8-18 December 1942), 17.
} 
thought this was best pursued through 'joint projects'. But the body responsible for reconstruction could not be simply 'another Commonwealth department', and should report directly to the treasurer. ${ }^{43}$

To emphasise that it was not another department, Post-War Reconstruction began as a ministry, that title encompassing the link between the commissions of inquiry and the research and administrative apparatus that served them. But as the commissions completed their work, they were replaced by departmental divisions (hence the Rural Division and the Secondary Industries Division) so that Post-War Reconstruction became a department, albeit one that was intended from the outset to have a finite existence. Its functions encompassed the preparation of plans for the transition from a wartime to a peacetime economy, along with a collaborative role in re-establishment of members of the services and war workers; the disposal of wartime buildings, plant and equipment; the maintenance and expansion of employment and the national income; the prevention of want and attainment of social security; and the development and conservation of the country's resources.

Coombs canvassed his ideas among colleagues and knowledge of his new role spread well in advance of its announcement. Ronald Walker wrote to Chifley early in November 1942 to welcome the Government's new resolve and endorse the combination of commissions and a 'central reconstruction secretariat'. While acknowledging the prior reluctance to embark on post-war reconstruction planning for fear of provoking domestic disunity, he warned that 'business men are already busy with their own plans to better their position in the post-war period', and stressed the urgency of mobilising public support for a genuine reconstruction. ${ }^{44}$

Coombs needed no such persuasion of the importance of public support. As Tim Rowse has explained, he paid particular attention to this aspect of the work of the Rationing Commission, ${ }^{45}$ and had already advised Chifley that the reconstruction organisation would need 'to provide a channel through which public and sectional desire for reconstruction can flow and canalise this political energy into effective channels and prevent the development of a sense of frustration'. At this formative stage he took advice from Brian Fitzpatrick, then working as industrial liaison and research officer for the Rationing Commission, who reinforced the importance of stiffening morale. ${ }^{46}$ He seems also to have been briefly impressed by the enigmatic Alf Conlon, who, in May 1942, had persuaded

\footnotetext{
43 Coombs, memorandum to Chifley, 22 October 1942, NAA M448/1, 109.

44 Walker to Chifley, 6 November 1942, NAA A9816/3, 1943/787.

45 T. Rowse, Nugget Coombs: A Reforming Life (Cambridge: Cambridge University Press, 2002), 92-9.

46 B. Fitzpatrick, 'Notes for Submission to the Honourable the Treasurer on Post-War Reconstruction Planning Organisation', n.d. [October 1941], NAA M481/1, 109; see also letters to Coombs, 27 September, 13 October 1942, Fitzpatrick Papers, NLA MS 4965/6/1-7.
} 
Curtin to establish a Committee on National Morale 'responsible directly to the prime minister and consisting only of distinguished and disinterested minds' - though the prime minister's confidence in these experts was dispelled by their overblown proposal at the end of the year for a 'National Public Relations Service' with an annual budget of more than $£ 1,000,000 .{ }^{47}$ The new department embarked on a range of activities to publicise its work - publications, broadcasts, service education - and established a substantial network of discussion groups.

The central office of the department was in Canberra, along with a policy and research division, but most of the commissions and the divisions that carried out the work were based in Melbourne and Sydney. First came the Rural Reconstruction Commission, announced on New Year's Day; the Reconstruction Training Committee was formed in March 1943, the Housing Commission in April, the National Works Council in July and the Secondary Industries Commission in October 1943. The department also inherited some initiatives, such as the Universities Commission, which was incorporated into an Office of Education in 1945. In the same year it absorbed the Department of War Organisation of Industry.

Other components of reconstruction were undertaken elsewhere. Hence the department played little part in the expansion of social services, which began with child endowment under the Menzies Government and extended to widows' pensions, the National Welfare fund, unemployment and sickness benefits, free medicine and hospital care. It was given responsibility for preparation of the White Paper on Full Employment, which lagged behind similar statements in Britain, the United States and Canada; and Coombs failed to carry one of his most ambitions proposals, a Department of Economic Planning.

No attempt will be made here to assess the work of these agencies. ${ }^{48}$ Rather, I shall venture some observations about the way the department worked that have implications for the era of the seven dwarfs.

My first observation is that Australia came late to the task of planning reconstruction. Coombs had scarcely begun his appointment as director-general before he was sent abroad to advise Evatt on negotiations in London, Washington and Hot Springs on post-war economic proposals, leaving Leslie Melville of the

\footnotetext{
47 'Report of Committee on Civilian Morale', n.d. [April 1942], and 'Plan for National Public Relations Service', n.d. [January 1943], NAA A5954, 328/21.

48 See H. Gallagher, We Got A Fair Go: A History of the Commonwealth Reconstruction Training Scheme, 1945-1952 (Melbourne: H. Gallagher, c. 2003); E. Jones, 'Post-World War Two Industry Policy: Opportunities and Constraints', Australian Economic History Review, 42, no. 3 (November 2002), 312-33; T. Whitford and D. Boadle, 'Australia's Rural Reconstruction Commission, 1943-46: A Reassessment', Australian Journal of Politics and History, 54, no. 4 (December 2008), 525-44; A.W. Martin and J. Penny, 'The Rural Reconstruction Commission, 1943-1947', Australian Journal of Politics and History, 29, no. 2 (1983), and other papers presented at the 1981 Conference on Post-War Reconstruction.
} 
Commonwealth Bank in charge of the new ministry. It was here that Coombs first expounded his 'positive approach' to Article VII of the Mutual Aid agreement, which linked domestic policies of full employment to the reduction of trade barriers, and he also found time to investigate the organisation of reconstruction planning in Britain. Reporting the failure of Jowitt's 'reconstruction secretariat' to exert any influence over the separate endeavours of various departments, he advised Chifley in July 1943 that '[t]his experience throws a lot of light on the problems which lie ahead of us'. But it would be some months before he could tackle them. ${ }^{49}$

The original idea was that the 'central reconstruction secretariat' would operate in tandem with the commissions, but in practice it lagged behind their investigations while they in turn were late in submitting the reports that were needed to set administrative arrangements in train. Coombs took care with his appointments - he sought out economics graduates such as Trevor Swan and Noel Butlin, and fought hard to secure the services of Flora Eldershaw - but sometimes had to make do with what he could get. One key appointment, that of Lloyd Ross as director of Public Relations, was imposed on him by the prime minister.

The recruitment of John Crawford revealed the flaws in the ministry's design. Crawford was working for the Rural Bank of New South Wales, and advising the Department of War Organisation of Industry, when Coombs invited him to become executive officer of the Rural Reconstruction Commission in January 1943. Crawford was wary of the ambiguities in this role, quickly fell out with members of the commission (whom he accused of 'preconceived and stupid prejudices') and within two months was threatening to resign. Coombs arranged for Crawford to become director of the Research Division, and his de facto deputy. ${ }^{50}$ When this dwarf left to become director of the Bureau of Agricultural Economics in 1945, his replacement was Allen Brown, an equally redoubtable bureaucratic infighter. Crawford and Brown honed their skills in the maze of interdepartmental committees - the department was represented on a score of them by 1945 - but other divisional heads with more specialist expertise struggled.

The director-general was absent for long periods after the war, representing Australia in international negotiations over finance and trade, but he alone was able to resolve the frequent disputes with other departments. 'You must remember', Firth advised a scholar investigating the history of post-war reconstruction, 'that in his prime Coombs was able to charm birds out of trees'.$^{51}$ Tange recalled Coombs as idealistic and rather romantic, but 'one of the most persuasive men that I have ever met' ${ }^{52}$ Alan Renouf, who accompanied Coombs

49 Coombs to Chifley, 12 July 1943, NAA M448/1, 109.

50 Correspondence between Crawford and Coombs, 21 January - 30 March 1943, NAA M448/1, 39.

51 G. Firth to M. Howard, 14 February 1975, NLA MS Acc. 01/273, Box 9A.

52 A. Tange, interviewed by J.D.B. Miller, March 1981, NLA TRC 1023. 
at the Havana Trade Conference, knew of no other Australian who exercised the same measure of intelligence, charm and persuasion. ${ }^{53}$ His special relationship with Chifley enabled him to overcome Treasury resistance to some of the programs prepared by Post-War Reconstruction, but not all of them - his proposals for community centres and special assistance to women with family responsibilities were among the casualties. After 1945, when Chifley passed the portfolio to Dedman but kept the Treasury, he was increasingly inclined to follow its advice. R.H. Tawney's comment on the British experience after the First World War 'For five years the Treasury had led a forlorn life. Now it crept from its corner making mournful noises' - had special force in Australia from 1945. ${ }^{54}$

A further difficulty was the uncertainty about the Commonwealth's powers for post-war reconstruction. At the Constitutional Convention in November 1942 the states undertook to transfer a wide range of powers, but in February 1943 the South Australian Parliament amended the enabling bill and it soon became apparent that other methods would be required. With an election due before the end of the year, however, Curtin was anxious to allay accusations that these powers would be used to impose socialism by stealth. Speaking at the Fremantle Town Hall on 29 April 1943, he declared that 'we have not socialised Australia and we don't intend to do so' ${ }^{55}$ Moreover, he was still adamant that invasion remained a real threat. Launching the third Liberty Loan on 28 March 1943, the prime minister said:

I am not interested in the kind of world we are to have when the war is over. I have given thought to it, but I do not delude myself. You need not worry about the Beveridge plan ... or Mr Chifley in his important task of reconstruction unless Japan is beaten. ${ }^{56}$

By June, Curtin was ready to concede that the imminent danger had passed, and in the subsequent election campaign he made much of Labor's plans for a new peacetime order. Yet it was not until August 1944 that the government sought the transfer of powers by referendum. That Curtin allowed Evatt to draft the terms of the referendum (especially the provision that all 14 powers should stand or fall together) and conduct the campaign remains a mystery.

The defeat of the referendum left the government reliant on wartime powers due to expire six months after the end of hostilities. This limitation bedevilled almost every field of reconstruction but its hampering effects were apparent long before the plebiscite. Many arrangements had to be determined during 1943

53 A. Renouf, The Champagne Trail: Experiences of a Diplomat (Melbourne: Sun Books, 1980), 37.

54 R.H. Tawney, 'The Abolition of Economic Controls', Economic History Review, 13, no. 1-2 (1943), 1-30.

55 Digest of Decisions and Announcements, 58 (12 April - 13 May 1943), 29.

56 Ibid., 56 (4 March - 1 April 1943), 43. 
and the first half of 1944 at meetings with the state premiers, and necessitated a series of debilitating compromises. The failure to catch the wartime enthusiasm for reconstruction at its flood was costly.

The problem was compounded by ministerial rivalries. Dedman, who hoped in 1942 that he would be given responsibility for reconstruction, maintained a millenarian fervour that contrasted with Chifley's more restrained advocacy. Coombs suggested that his minister make an early statement of the broad objectives, and provided a draft. 'There is a danger', it warned, 'that reconstruction will become a magic word and create dreams that cannot be realised ${ }^{\prime}{ }^{57}$ The minister became more expansive after the 1943 election removed these constraints, though tight controls were maintained on statements from departmental staff.

The machinations of Evatt were far more damaging. His interest in post-war reconstruction fluctuated after his initial appointment in 1941 as director of research, which was conspicuously unproductive. Through John Burton, he kept up an interest during 1942 in the Inter-Departmental Committee on External Relations. As attorney-general, he was responsible for preparing the Constitutional Convention and summoned Crisp and Firth to join a team of public servants in Melbourne who prepared a lengthy Case for Greater Commonwealth Powers. ${ }^{58}$ Evatt came late to an appreciation of the 'positive approach' to international economic arrangements, but took it up as part of his endeavour to assert an Australian influence in world affairs. To this end he had Tange transferred to the Department of External Affairs as a liaison officer early in 1944. ${ }^{59}$

Evatt's ally, J.A. Beasley, represented Australia at the International Labour Organization conference at Philadelphia in April 1944; against the advice of the economists, Beasley pursued an explicit commitment to full employment so hamfistedly that the Americans withdrew their support for a broader endorsement. When the Australians did not get their way at the United Nations Monetary and Financial Conference at Bretton Woods in July 1944, Evatt instructed the delegation led by Leslie Melville not to sign the final record. It was fortunate that Roland Wilson accompanied Evatt and Frank Forde, the deputy prime minister, to the founding meeting of the United Nations at San Francisco in 1945, for Wilson was conspicuously immune to browbeating, but Evatt persisted nevertheless in inserting a weak provision for full employment into the United

\footnotetext{
57 Coombs to Chifley, 'Draft Policy Broadcast', 20 April 1943, NAA M448/1, 109; Chifley's use of these words is recorded in the transcript of his broadcast on 17 May 1943, Dedman Papers, NLA MS 987/1/508.

58 H.V. Evatt, Post-War Reconstruction: A Case for Greater Commonwealth Powers Prepared for the Constitutional Convention at Canberra (Melbourne: Government Printer, 1942); the minutes of the editorial committee are in the Fitzpatrick Papers, NLA MS 4965/6/86-92.

59 Tange to Crawford, 'Liaison Work in External Affairs', NAA M448/1, 110.
} 
Nations Charter that lacked any machinery for its realisation. ${ }^{60}$ Evatt was a constant vexation to Curtin; the normally imperturbable Chifley referred to him as 'my learned and no doubt very able friend down the passage'.$^{61}$

The rise of the seven dwarfs brought economists into senior administrative posts, but they remained answerable to their ministers and the Cabinet, and it was their skill in managing this relationship that enabled them to prosper. There is an instructive contrast with James Brigden, the secretary of the Department of Munitions, who was dismissed after he clashed with his minister. Brigden (born in 1887), along with Copland (1894), Giblin (1872) and Richard Mills (1886), was one of the cohort of older economists who occupied important posts in the wartime government; but they came late to public service and did not aspire to build careers in it. They did nurture the careers of younger economists such as Coombs (born 1906), Crawford (1910) and Wilson (1904), who rose to prominence during the war and who by 1945 had overtaken their mentors in rank and influence. Giblin accepted this transformation readily; hence his recommendation of Coombs to Keynes as 'a good fellow, solid, no frills, no disturbing ego, very reasonable, though there is ground where I - Wilson also cannot follow him' ${ }^{62}$ Copland found the supersession more difficult.

Those economists, younger still, who began their public service careers in the Department of Post-War Reconstruction encountered a particular challenge. As Tange would recall, 'We in PWR were seen as inexperienced new boys wearing fancy academic dress, theorising without the benefit of ever having negotiated a tariff agreement or a bulk commodity arrangement'. ${ }^{63}$ Some reverted to academic dress - hence Firth, Butlin, Swan and Crisp, the last head of the department before its abolition in 1950. Others stayed on to apply their newly acquired skills to departmental administration. At the outbreak of war the Commonwealth Public Service consisted of 47,000 persons; by the last years of the war it had doubled in size and in the post-war period it continued to grow. In the course of the war 17 new departments were created as the Commonwealth began a lasting involvement in banking, employment, primary and secondary industries, shipping and transport, power, irrigation, health and social services. To direct these activities a new cadre of senior public servants was required, skilled in policy, administration and the exercise of power. This was the setting for the seven dwarfs.

60 The fullest account is S.R. Turnell, 'Monetary Reformers, Amateur Idealists and Keynesian Crusaders: Australian Economists' International Advocacy 1925-50', PhD thesis, Macquarie University, 1999.

61 As reported by E.H. Cox, 1 November 1946, Cox Papers, NLA MS 4554.

62 Quoted in W. Coleman, S. Cornish and A. Hagger, Giblin's Platoon: The Trials and Triumph of the Economist in Australian Public Life (Canberra: ANU E Press, 2006), 178, n. 9.

63 A. Tange, 'Plans for the World Economy: Hopes and Realities in Wartime Canberra', Australian Journal of International Affairs, 50, no. 3 (November 1996), 261. 
This text is taken from The Seven Dwarfs and the Age of the Mandarins: Australian Government Administration in the Post-War Reconstruction Era, edited by Samuel Furphy, published 2015 by ANU Press, The Australian National University, Canberra, Australia. 